\title{
The Effect of the Challawa Industrial Estate on the Physicochemical Properties and Heavy Metal Levels of Portable Water Supply in Kano Metropolis, Nigeria
}

\author{
Abdulrahman Audu, Abdulhakeem Idowu \\ Department of Pure and Industrial Chemistry, Bayero University, Kano, Nigeria \\ Email: aa audu@yahoo.com
}

Received December 2014

\begin{abstract}
It has been observed that the portable water quality obtained from various locations in Kano Metropolis has shown greater variations in the recent past. Attempts have been made to ascertain the reasons for the variations even though the supplies were from only two treatments plants that obtain their raw water from the same source. A total of 92 water samples comprising of raw (from plants) and treated (from the plants and taps) were collected during rainy and dry seasons between April 2010 and May, 2012 and analyzed using standard analytical techniques. The results of analysis gave the physiochemical properties with range as follows: $\mathrm{pH}(0.06 \pm 6.7-6.04 \pm 0.02)$ conductivity $(7.23 \pm 0.04-13.33 \pm 0.22 \mathrm{~S} / \mathrm{Cm})$, turbidity $(5.00 \pm 0.01-449.22 \pm 1.32 \mathrm{NTU})$, suspended solids $\left(107.33 \pm 3.45-712.11 \pm 5.33 \mathrm{mg} / \mathrm{dm}^{3}\right)$, total dissolved solids $(18.50 \pm 0.85-186.78 \pm$ $\left.2.48 \mathrm{mg} / \mathrm{dm}^{3}\right)$, alkalinity $\left(12.53 \pm 0.32-80.75 \pm 1.23 \mathrm{mg} / \mathrm{dm}^{3}\right)$ and hardness $(29.50 \pm 1.22-58.67$ $\pm 2.34 \mathrm{mg} / \mathrm{dm}^{3}$ ). The $\mathrm{pH}$ values were generally acidic while the turbidity and total solid especially in some locations were higher than the permissible levels set by the World Health Organization for portable water. The concentration of heavy metals $\left(\mathrm{mg} / \mathrm{dm}^{3)}\right.$ were found in the following ranges Fe (0.10 $\pm 0.04-0.30 \pm 0.02)$, Cu $(0.01 \pm 0.001-0.03 \pm 0.002), Z n(0.13 \pm 0.06-0.39 \pm 0.02)$, $\mathrm{Pb}(0.03 \pm 0.01-0.17 \pm 0.02)$, Mn $(0.03 \pm 0.004-0.13 \pm 0.003), \operatorname{Cr}(0.10 \pm 0.04-0.31 \pm 0.03)$. The highest values of $\mathrm{Fe}, \mathrm{Cu}$ and $\mathrm{Mn}$ were recorded along the older distribution channel of Challawa. The levels of $\mathrm{Pb}$ and $\mathrm{Cr}$ were generally high in both routes which are also observed in the raw water used at the two treatments plants. The results obtained from heavy metal concentrations fell within the maximum allowable limit set by the World Health Organization for portable water except in the cases of $\mathrm{Pb}$ and $\mathrm{Cr}$. The high $\mathrm{Fe}, \mathrm{Mn}, \mathrm{Cu}$ levels as obtained in the Challawa route were attributed to leaching from rusting in the old galvanized metal pipe-work in the distribution channel. The levels of chromium and lead were similar in the two networks showing that the raw water used in the both treatment plants were responsible for the high values obtained and were not effectively removed by the treatment processes.
\end{abstract}

\section{Keywords}

Heavy Metals, Industrial Estate, Kano Metropolis, Water 


\section{Introduction}

Water is one of the most common substances known, being a good solvent for many materials but rarely exists in its pure form in nature. Natural sources of water include rain, spring, well, river, lake and sea. Rain water is the purest form of natural water because it is formed as a result of the condensation of water vapour in the atmosphere and can be classified as a natural form of distilled water. The water from the other sources especially river, lake and sea, contains a lot of impurities which include dissolved gases, mineral salts, bacteria and organic remains. As a result, drinking from these sources without proper purification has caused various forms of health related diseases in humans [1] [2].

Metals are introduced into aquatic systems through several ways, which include weathering of rocks and leaching of soils, dissolution of aerosol particles from the atmosphere and from several human activities, including mining, processing and the use of metal based materials [1] [3] [4]. Other common sources of introducing heavy metals are from decomposing vegetation and animal matter. The role of trace metals in biochemical life processes of aquatic plants and animals and their presence in trace amounts in the aquatic environment are essential. However, at high concentrations, these trace metals become toxic [5] Ingestion of heavy metals such as lead $(\mathrm{Pb})$, Cadmium (Cd), mercury ( $\mathrm{Hg})$, Chromium (Cr) from water pose great risks to human health [6].

Faecal pollution of drinking water causes water-borne diseases, which have led to the deaths of millions of people both in cities and villages [2]. The dynamic balance in the aquatic ecosystem is upset by human activities, resulting in pollution which is manifested dramatically as fish kill, offensive poor taste, odour, colour and unchecked aquatic weeds [7].

The availability of good quality water is an indispensable feature for preventing diseases and improving quality of life [8]. Water quality deals with the physical, chemical and biological characteristics in relation to all other hydrological properties. The concentration and composition of dissolved constituents in water determine its quality for irrigation use also. Quality of water is an important consideration in any appraisal of salinity or alkali conditions in an irrigated area. Good quality water has the potential to cause maximum yield, while poor quality water can develop various soil and cropping problems. Between the wide diversity of pollutants affecting water resources, heavy metals receive particular concern considering their strong toxicity even at low concentrations [9].

A water supply system or water supply network is a system of engineered hydrologic and hydraulic components which provide water supply. Raw water is collected from a surface water or ground water source within the water shed that provides the water resource then is transferred to the water purification facilities using uncovered aqueducts, covered tunnels or underground water pipes. The product delivered to the point of consumption as fresh water if it receives little or no treatment or drinking water if the treatment achieves the water quality standards required for human consumption.

As water passes through the distribution system, the quality can degrade by chemical reactions and biological processes. Corrosion of metal pipe materials in the distribution system can cause the release of metals into the water with undesirable aesthetic and health effects. The release of iron from unlined iron pipes can result in customer reports of "red water" at the tap. Release of copper from pipes can result in customer reports of "blue water" and/or a metallic taste. Release of lead can occur from the solder used to join copper pipe together or from brass fixtures.

Kano is the largest and the most populous city in Nigeria with more than ten million inhabitants [10]. It is also the commercial nerve centre of northern Nigeria receiving traders from Niger, Mali, Chad, Barkinafaso and Ghana.

The Tiga dam which was constructed in 1974 is a major reservoir on the Kano River and provides the water needs in the metropolitan Kano for drinking and other household uses, in addition for the irrigation projects [11]. Since the Tiga dam also receives a considerable amounts of municipal, industrial and agricultural waste water, a combination of physical, chemical and bacteriological treatments are employed at the Challawa and Tamburawa Water Treatment plants. The main mode of transportation of water in the Kano Metropolis is through pipe materials after treatment.

In the recent past the results of the physicochemical assessments of water supply in the metropolis has shown great variations. In some parts of the old Kano city, the aesthetic appearance of the water obtained from taps have become so poor that inhabitants have to complain to the Kano Municipal Water Board. This study was aimed at ascertaining the physicochemical properties and the heavy metal levels of the water supplied from the 
Challawa and Tamburawa plants to the metropolitan Kano with a view to determining the contributory effects of the distribution systems on the water quality.

\section{Materials and Methods}

Standard analytical techniques were employed in the determinations of the physicochemical properties of the water samples. The heavy metal levels were determined using Atomic Absorption Spectrophotometric methods after wet digestion [12].

\section{Sampling and Sample Collection}

Two sampling points (Raw water and Treated water) were identified at the Tamburawa Treatment plant. Between the plant and the end of the distribution system where the main reservoir is situated, were identified seven sampling points. These were selected based on the settlements along the distribution route.

Similarly, two sampling points (Raw water and Treated water) were identified at the Challawa Treatment plant and between the plant and Kabuga where the main treated water reservoir is situated were identified six other sampling points.

Water samples were collected in dark colored 4-liter and 1-liter plastic bottles which have been previously treated with $10 \% \mathrm{HNO}_{3}$ and 1:1 $\mathrm{HCL}$ for 48 hours washed, rinsed with distilled deionised water and dried in an oven at $50^{\circ} \mathrm{C}$ overnight [13].

A total of 92 samples were collected in the two rainy and dry seasons from late 2009 and May 2012 from the selected points. All samples were collected within 12 hours for every route. The samples for elemental analysis were collected in the 4-liter plastic containers and were immediately acidified with $1.0 \mathrm{~cm}^{3}$ of concentrated nitric acid while the samples in the 1.liter plastic bottles were used as collected for the physicochemical studies [14] [15].

The determination of the heavy metal levels were as described [16] whereby $4000 \mathrm{~cm}^{3}$ of each water sample was reduced to $200 \mathrm{~cm}^{3}$ by evaporation. This is achieved by sequentially taking about $500 \mathrm{~cm}^{3}$ of the water sample in a $1000 \mathrm{~cm}^{3}$ capacity pyrex glass beaker and heated on a hot plate until the volume is reduced to about $200 \mathrm{~cm}^{3}$. The process was repeated whereby more of the water sample was added and made up to $500 \mathrm{~cm}^{3}$ and similarly evaporated to $200 \mathrm{~cm}^{3}$. This process was continued until the $4000 \mathrm{~cm}^{3}$ sample has been reduced to 200 $\mathrm{cm}^{3}$ capacity. To the resultant $200 \mathrm{~cm}^{3}$ water sample was added $5.0 \mathrm{~cm}^{3}$ of concentrated nitric acid and heated on the hot plate at $105^{\circ} \mathrm{C}$ under reflux five hours. It was then allowed to dry to about $25 \mathrm{~cm}^{3}$ solution and set aside to cool to room temperature. This was then filtered using a whatman No. 42 filter paper into a $50 \mathrm{~cm}^{3}$ standard flask and made to mark with more distilled deionised water.

The metal levels of the sample were determined using Alpha 4 Atomic Absorption Spectrophotometer following the manufacturer's manual.

\section{Results and Discussion}

The $\mathrm{pH}$ values show that the raw water at both treatment plants were slightly acidic but within the minimum values specified by WHO. There are sharp decreases in $\mathrm{pH}$ values at GD and SAYC where values of $5.7 \pm 0.5$ and $6.0 \pm 05$ respectively were obtained. Comparing the result of the $\mathrm{pH}$ for the raw water and the average $\mathrm{pH}$ value of the water from the consumption points there is indication that the treatment procedures at the plants have not been able to raise the $\mathrm{pH}$ to the optimal value demanded for portable water, by both the NAFDAC (6.5 - 8.5) and the WHO (6.5 - 9.5)

Not much variations were noticed in the turbidity values as received at the consumption points on the Tamburawa (TAM) route when compared to erratic values obtained at some consumption points on the Challawa (CHA) route such as GD(647.7 \pm 99.2$)$ and SAYC $(706.5 \pm 90.4)$ as shown in Figure 1. This would be as a result of the constant repairs of the old steel pipes during which sand, mud and other dirts get accumulated in the disconnected pipes through run-offs in the rainy especially at the sites before the reconnection after the repairs. When treated water is supplied, the accumulated dirt thus increases the water turbidity. Such repairs points were not yet observed on the pipe network in the Tamburawa route since these were newly laid as such turbidity values only ranged between $4.5 \pm 0.1$ at the end of the route and $5.7 \pm 0.2$ for the treated water at the Tamburawa plant. The value of $4.5 \pm 0.1$ obtained at the end of the route showed that more of the suspended solids were being precipitated as the treated water travelled from the treatment plant. Other physicochemical properties of the 
processed water at both plants and at the consumption points within the routes met the WHO specifications. The levels of suspended and dissolved solids at GD, SAYC and DRY were higher than the NAFDAC and SON specifications for drinking water.

Comparing the metal levels as shown in Figure 2 and Figure 3 obtained in the treated water at both plants and those obtained along the routes, it could be clearly observed that the treatment processes have not effectively removed the heavy metals. In Figure 2, the metal levels at the seven points along the routes relates closely with those values at the treatment plant for the water samples. This basically indicates that the treated water sample as obtained at the Tamburawa plant maintained its quality through the distribution system. This is unlike what is observed in Figure 3 as the metal levels showed quite erratic levels as the treated water moved through the pipe network to KBG. Relative increases in the metal levels were noticed, indicating that water quality was not maintained as it is being distributed. This observation can be attributed to leaching from the old pipes and also corrosion from the weld points in the pipes along the routes.

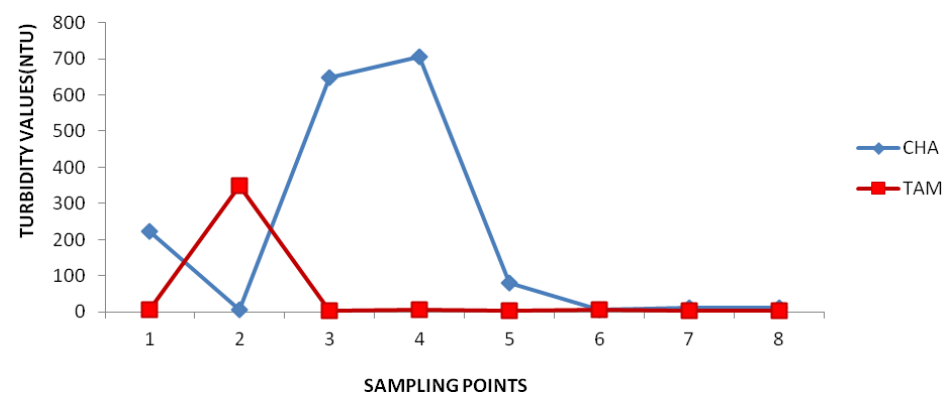

Figure 1. Turbidity values along the challawa and tamburawa routes.

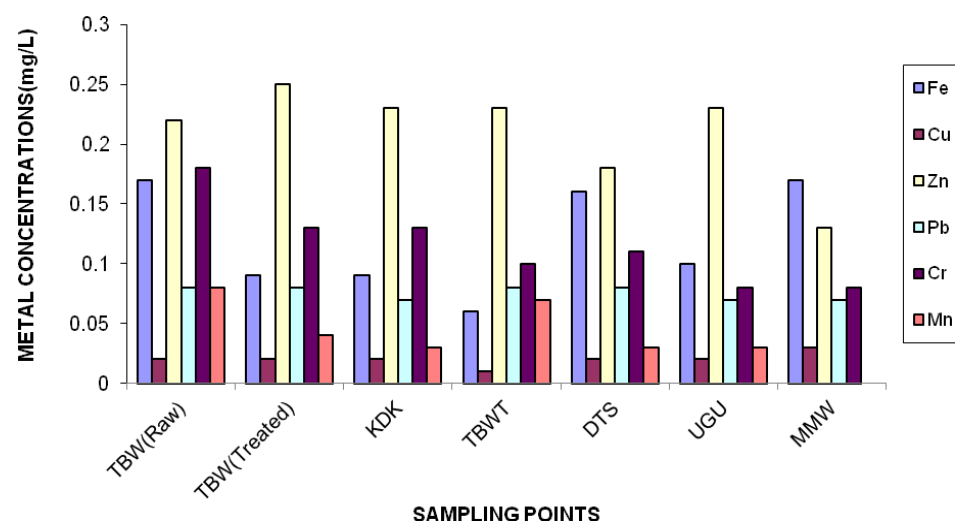

Figure 2. Average metal levels at the sampling points on the tamburawa route.

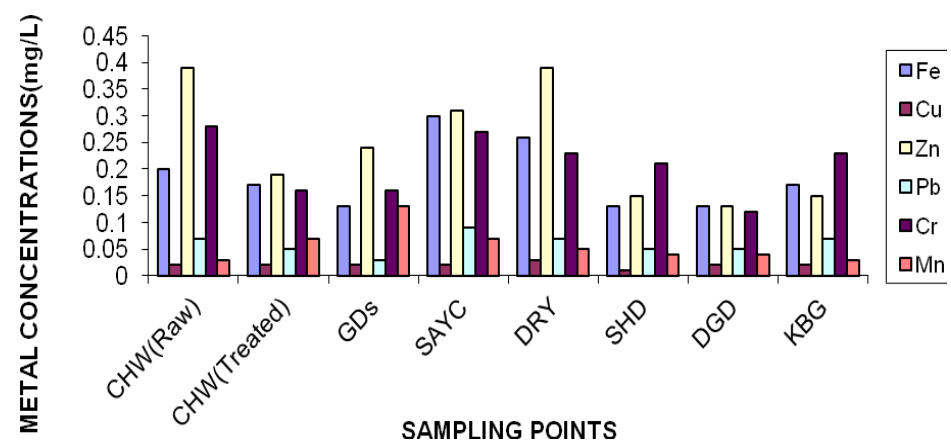

Figure 3. Average metal levels at the sampling points on the challawa route. 
Though $21 \%$ and $50 \%$ of $\mathrm{Cr}$ content of the raw water were removed by the treatment methods of Challawa and Tamburwa respectively yet the procedures did not produce portable water quality that would meet the standards set by WHO, NAFDAC or SON as the residual metal levels were $107 \%$ and $210 \%$ higher than the standard at Tamburawa and Challawa respectively. From the data obtained at both plants, the treatment procedures did not remove the lead content of the raw water to any appreciable level, indicating high threat to human health by the consumption of the water from both plants. The highest levels of Fe and Mn were obtained at Gaida, Dorayi and SAYC consumption points. These levels which were higher than what was obtained at the treatment points show that leaching of corroded steel pipe surfaces have occurred in the distributions network.

Generally the metal levels in the treated water were higher in the rainy season showing that more dissolved salts must have been washed into the raw water body that is more than can be effectively removed by the water treatment processes.

\section{Conclusion}

It has been observed that the two treatment plants have not perfected procedures that would reduce the levels of lead and chromium in the treated water to the WHO specifications levels. Very erratic changes in the metal levels were observed in the water at some points on the Challawa route which have been related to leaching from the corroded pipe work and also contamination from run offs into damaged pipe networks.

\section{Recommendations}

The treatment plants should review their raw water treatment procedures with a view to ensuring that heavy metal levels were reduced to below the WHO limits. That water treatment procedures should be developed to take into consideration seasonal changes in the raw water properties. Old pipes in the Challawa route network should be replaced and not repaired.

\section{References}

[1] Adeyeye, E.I. (1994) Determinations of Heavy Metals in Illisha Africana Associated with Water, Soil and Sediments from Some Fish Ponds. International Journal of Environmental Studies, 45, 231-240. http://dx.doi.org/10.1080/00207239408710898

[2] Asaolu, S.S. (1998) Chemical Pollution Studies of Coastal Water of Ondo State. Unpublished Ph.D., Thesis Department of Chemistry, Federal University of Technology, Akure.

[3] Ipinmoroti and Oshodi (1993)

[4] Asaolu, S.S., Ipinmoroti, K.O., Adeyinowo, C.E. and Olaofe, O. (1997) Interrelationship of Heavy Metals Concentrations in Water, Sediments and Fish Samples from Ondo State Coastal Area. Nig. Afri. Journal Sci., 1, 55-61.

[5] Clesceri, L.S. and Greenberg, A.E. (1998) Standard Methods for the Examination of Water and Wastewater. 20th Edition, American Public Health Association.

[6] Kennish et al. (1992)

[7] Adefemi, S.O. and Awokunmi, E.E. (2010) Determination of Physicochemical Parameters and Heavy Metals in Water Samples from Itaoqbolu Area of Ondo State. African Journal of Environmental Sciences and Technology, 4, 145-148.

[8] Dinrifo, R.R., Babatunde, S.O.E., Bankole and Demu, Q.A. (2010) Physicochemical Properties of Rain Water Collected from Some Industrial Areas of Lagos State. Nigeria European Journal of Scientific Research, 41, 383-390.

[9] Ervin, D.E., Kahn, J.R. and Livingston, M.L. (2003) Does Environmental Policy Work?: The Theory and Practices of Outcomes Assessment. Edward Elgar Publishing, 70-82.

[10] National Population Commission (2006) The Nigerian Population Census. Published by NPC, Abuja.

[11] Barbier, E.B. (2002) Upstream Dams and Downstream Water Allocation. The Case of the Hadejia Jama'are Flood Plain, Northern Nigeria. Unpublished Ph.D. Thesis Submitted to the Department of Economics and Finance, University of Wyoming, USA.

[12] Idowu, A.A. (2012) The Effect of Distribution on the Physicochemical Properties and Heavy Metal Levels of Water Supply in Kano Metropolis. Unpublished MSc Dissertation, Department of Pure and Industrial Chemistry, Bayero University, Kano.

[13] Adefemi and Awokunmi (2009) 
[14] Ademoroti, C.M.A. (1996) Standard Methods for Water and Effluent Analysis. Foludex Press Ltd., Ibadan.

[15] World Health Organisation (2004) Guidelines for Drinking water Quality. 3rd Edition.

[16] Kar et al. (2008) 